\title{
Reclassification of Pediococcus dextrinicus (Coster and White 1964) Back 1978 (Approved Lists 1980) as Lactobacillus dextrinicus comb. nov., and emended description of the genus Lactobacillus
}

\author{
Monique Haakensen, ${ }^{1}$ C. Melissa Dobson, ${ }^{2}$ Janet E. Hill ${ }^{3}$ and Barry Ziola ${ }^{1}$ \\ ${ }^{1}$ Department of Pathology and Laboratory Medicine, University of Saskatchewan, 2841 Royal \\ University Hospital, 103 Hospital Drive, Saskatoon SK S7N OW8, Canada \\ ${ }^{2}$ CanBiocin, \#1015 - 8308114 Street, Edmonton AB T6G 2E1, Canada \\ ${ }^{3}$ Department of Veterinary Microbiology, University of Saskatchewan, 52 Campus Drive, Saskatoon \\ SK S7N 5B4, Canada
}

Correspondence

Barry Ziola

b.ziola@usask.ca
The taxonomic status of Pediococcus dextrinicus is described and transfer of the species to the genus Lactobacillus, with the name Lactobacillus dextrinicus comb. nov., is proposed. This reclassification is supported by multilocus sequence analysis of the 16S rRNA gene and Cpn60, PheS, RecA and RpoA proteins. The mode of cell division and existing phenotypic information also show that $P$. dextrinicus does not belong to the genus Pediococcus, but rather to the genus Lactobacillus. As such, we propose that Pediococcus dextrinicus is reclassified as Lactobacillus dextrinicus comb. nov. (type strain ATCC $33087^{\top}=\mathrm{DSM} 20335^{\top}=\mathrm{JCM} 5887^{\top}=\mathrm{LMG}$ $11485^{\top}=$ NCDO $1561^{\top}$ ).
The genus Pediococcus currently consists of 13 species (correct at the time of writing), including Pediococcus acidilactici, Pediococcus claussenii (Dobson et al., 2002), Pediococcus cellicola (Zhang et al., 2005), Pediococcus damnosus, Pediococcus dextrinicus, Pediococcus ethanolidurans (Liu et al., 2006), Pediococcus inopinatus, Pediococcus parvulus, Pediococcus pentosaceus, Pediococcus siamensis (Tanasupawat et al., 2007) and Pediococcus stilesii (Franz et al., 2006). Two additional species originally classified as members of the genus Pediococcus have been transferred to other genera. Pediococci are homofermentative and produce DL-lactate from glucose; the exceptions being $P$. claussenii and P. dextrinicus which produce only $(+)$-L-lactic acid (Dobson et al., 2002; Franz et al., 2006; Pederson, 1949).

The species $P$. dextrinicus was included within the genus Pediococcus based upon morphology, cell-wall composition, homofermentative lactic acid production and nutritional requirements (Coster \& White, 1964). It should be noted, however, that many of these characteristics are also shared by other lactic acid bacteria, including the related genera Aerococcus, Lactobacillus and Tetragenococcus. Gunther \& White (1961a) first introduced the term 'Group III' for what is now $P$. dextrinicus, but unlike Pediococcus Groups I and II, Group III was referred to as the 'Possible Group III' as it was less well defined and

Abbreviation: MLSA, multilocus sequence analysis. differed from Groups I and II (true pediococci) in many phenotypic properties. Group III organisms most resembled Pediococcus halophilus (now reclassified as Tetragenococcus halophilus), except for salt tolerance. Gunther \& White (1961a) went further to say it is felt that insufficient evidence is at present available on which to base the establishment of this group at specific rank'. The original descriptions of $P$. dextrinicus (originally referred to as 'Group III Pediococcus' by Gunther \& White, 1961a, b, and later as 'Pediococcus cerevisiae subsp. dextrinicus' by Coster \& White, 1964), describe $P$. dextrinicus as being very different from all other Pediococcus isolates and their findings indicated that $P$. dextrinicus may in fact be more closely related to members of the genus Staphylococcus (Coster \& White, 1964). It was mentioned that $P$. dextrinicus strains 'are not related antigenically to P. cerevisiae (Group I) and $P$. parvulus (Group II). They may possibly represent a separate serological group' (Gunther \& White, 1961b). In 1964, Coster \& White noticed that 'Group III (now P. dextrinicus) extracts did not react with antisera prepared against strains other than group III', yet antisera produced to isolates found in Groups I and II show extensive crossreactivity with bacteria in both Groups. Serological data thus indicate that $P$. dextrinicus does not group with other pediococci.

At that point, the genus Pediococcus was too diverse to exclude $P$. dextrinicus as the genus still contained bacteria 
that have since been reclassified to the genera Aerococcus and Tetragenococcus. As such, $P$. dextrinicus was elevated to species status not based upon properties that included it within the genus Pediococcus, but based on the fact that it could not be included with any of the other species that had arisen from the original grouping of 'Pediococcus cerevisiae' (Back, 1978). In addition to the serological data presented by Gunther \& White (1961b) and Coster \& White (1964), several phenotypic properties also distinguish $P$. dextrinicus from other pediococci, including the lack of acid production from growth on trehalose, production of $\mathrm{CO}_{2}$ from gluconate, lack of growth at $\mathrm{pH} 4.5$ and the ability to hydrolyse starch and dextrin (Dellaglio \& Torriani, 2006; Franz et al., 2006; Holzapfel et al., 2006; Simpson \& Taguchi, 1995; Weiss, 1992). The phenotypic differences between $P$. dextrinicus and other pediococci are summarized in Table 1. For comparative purposes, the genera Aerococcus and Tetragenococcus are included in Table 1 as these bacteria were previously classified as pediococci. While $P$. dextrinicus can be excluded from the genus Pediococcus based upon the phenotypic properties in Table 1, these data also show that there are no phenotypic properties which can distinguish $P$. dextrinicus from members of the genus Lactobacillus.

Although the mode of division of $P$. dextrinicus has been listed as conforming to that of the genus Pediococcus, there is no published microscopy work documenting this and, interestingly, the original description of $P$. dextrinicus did

Table 1. Phenotypic characteristics that differentiate $P$. dextrinicus from related genera, but not from the genus Lactobacillus

Taxa: 1, Aerococcus; 2, Lactobacillus; 3, P. dextrinicus; 4, Pediococcus; 5 , Tetragenococcus. + , Positive; - , negative; $+/-$, genus includes species that are both positive and negative. Data adapted from Dellaglio \& Torriani (2006), Franz et al. (2006), Hammes \& Hertel (2006), Simpson \& Taguchi (1995) and Weiss (1992).

\begin{tabular}{|c|c|c|c|c|c|}
\hline Characteristic & $1^{\star}$ & 2 & 3 & $4 \dagger$ & $5^{\star}$ \\
\hline \multicolumn{6}{|c|}{ Production of acid from: } \\
\hline Starch & - & $+1-$ & + & - & - \\
\hline Dextrin & + & $+1-$ & + & - & - \\
\hline Trehalose & + & $+1-$ & - & + & + \\
\hline Mannose & + & $+1-$ & - & + & + \\
\hline Gas from gluconate & - & $+1-$ & + & - & - \\
\hline $\begin{array}{l}\text { Configuration of } \\
\text { lactate }\end{array}$ & $(+)-\mathrm{L}$ & $\begin{array}{l}\mathrm{D},(+)- \\
\quad \mathrm{L}, \mathrm{DL}\end{array}$ & $(+)-\mathrm{L}$ & DL $\neq$ & $(+)-\mathrm{L}$ \\
\hline \multicolumn{6}{|l|}{ Growth in/at: } \\
\hline $6.5 \% \mathrm{NaCl}$ & + & $+1-$ & - & $+\S$ & + \\
\hline $\mathrm{pH} 4.5$ & - & $+1-$ & - & + & - \\
\hline
\end{tabular}

*The genera Aerococcus and Tetragenococcus both contain isolates that were once classified as Pediococcus species.

$\dagger$ Includes current species of the genus Pediococcus, except for P. dextrinicus. $\ddagger$ All except $P$. claussenii which produces only $(+)$-L lactate.

$\$$ All except $P$. damnosus. not include the mode of division (Gunther \& White, 1961a, b; Coster \& White, 1964). It was not until P. dextrinicus was elevated to species status by Back (1978) that the description of the organism was expanded to include 'occurring predominantly in pairs and tetrads, occasionally in short chains and irregular clusters'. This ability to form chains differentiates $P$. dextrinicus from the descriptions of all other species of the genus Pediococcus (Simpson \& Taguchi, 1995). Clarification of the mode of division of $P$. dextrinicus is clearly necessary for a proper description of this bacteria.

In addition to these differences in phenotype and mode of division, it has been shown based upon 16S rRNA gene, cpn60 gene and protein and 16S-23S rRNA interspacer sequences that $P$. dextrinicus is phylogenetically distant to other pediococci, belonging instead within the genus Lactobacillus (Collins et al., 1991; Dobson et al., 2002; Franz et al., 2006). Despite the extensive documentation showing that $P$. dextrinicus are not pediococci, no formal reclassification of $P$. dextrinicus has been proposed. As such, the aim of the present study is the evaluation and clarification of the taxonomic position of this species.

\section{Mode of division}

We compared Gram-stains of $P$. dextrinicus with other species of the genus Pediococcus by counting the number of cells present as singles, pairs, tetrads and clusters (Table 2). There were no statistically significant differences found for the cell arrangements between: fields of view, isolates of the same species, growth phase or medium ( $t$-test for

Table 2. Results of cell division

\begin{tabular}{|lrrcc|}
\hline Species $^{*}$ & \multicolumn{4}{c|}{ Cell arrangement $\dagger$} \\
\cline { 2 - 5 } & Single & Pair & Tetrad $\ddagger$ & Cluster $\$$ \\
\hline P. acidilactici & 2 & 12 & 76 & 0 \\
P. claussenii & 2 & 2 & 96 & 0 \\
P. dextrinicus & 13 & 20 & 0 & 67 \\
P. inopinatus & 4 & 4 & 92 & 0 \\
P. parvulus & 12 & 20 & 68 & 0 \\
P. pentosaceus & 4 & 56 & 40 & 0 \\
\hline
\end{tabular}

${ }^{\star}$ Isolates used: P. acidilactici ATCC 8042, ATCC 25740; P. claussenii ATCC BAA-344 ${ }^{\mathrm{T}}$, CCC B1099; P. dextrinicus ATCC $33087^{\mathrm{T}}$, ATCC 700477; P. inopinatus ATCC $49902^{\mathrm{T}}$; P. parvulus ATCC 43013, Spain 2.6; P. pentosaceus ATCC 33314, ATCC 8081.

$\dagger$ There was no statistically significant difference found between: fields of view, isolates of the same species, growth phase or type of medium ( $t$-test; all $P$-values $>0.05$ ); consequently, numbers given are the mean number determined by counting 100 bacteria in each of five separate fields of view, from colonies taken from agar plates, and also at both log- and plateau-phase from broth medium.

$\ddagger$ Symmetrical groups of four cells with two perpendicular lines of division.

\$Three or more bacteria that were not symmetrical. Clumps of $>10$ bacteria were frequently observed. 


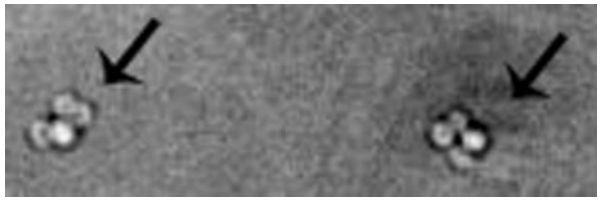

Fig. 1. Clusters of four cells of $P$. dextrinicus ATCC $33087^{\top}$ produced after division from a single cell. Image taken by phasecontrast microscope.

independent samples; all $P$-values $>0.05$ ). In this assessment of cell division, clusters were defined as groups of three or more cells that were not symmetrical and tetrads were defined as symmetrical groups of four cells (Simpson, 1994). This microscopy work strongly indicated that $P$. dextrinicus does not divide using a process like that of other pediococci. To confirm this, single cells of $P$. claussenii ATCC BAA- $344^{\mathrm{T}}$ and $P$. dextrinicus ATCC $33087^{\mathrm{T}}$ were followed through a minimum of two cycles of division (division from one to four cells) using phase-contrast microscopy. Cells of $P$. claussenii ATCC BAA $-344^{\mathrm{T}}$ divided in two perpendicular directions on a single plane and, once a tetrad was achieved, the four cells split into two doublets along the first line of division. In contrast, cells resulting from the two cell divisions of $P$. dextrinicus were not perpendicular to each other nor were they in a single plane. Moreover, $P$. dextrinicus cells did not separate upon becoming a group of four, but continued to divide, creating large irregular clusters, many of which contained $>10$ cells. Fig. 1 shows the result of division from one to four cells for two $P$. dextrinicus cells, while Fig. 2 represents $P$. dextrinicus cell division schematically compared with that given in the genus description for Pediococcus (Simpson, 1994). While these results suggest a different arrangement and mode of division for $P$. dextrinicus as compared with other pediococci (i.e. nonperpendicular cell arrangement and non-division after tetrad formation but formation of larger clumps), the exact mode of division needs to be further examined, including studies using scanning electron microscopy.

\section{Multilocus sequence analysis}

Although $16 \mathrm{~S}$ rRNA gene sequences are commonly used to elucidate phylogenetic relationships (Woese, 1987), using $16 S$ rRNA gene sequences to infer phylogeny has been criticized as it assumes that one molecule can reflect organismal evolutionary history (Fox et al., 1992). As such, instead of using just the 16S rRNA gene to infer phylogeny, we used a multilocus sequence analysis (MLSA) to assess the relationship of $P$. dextrinicus to other species of the genus Pediococcus, species of the genus Lactobacillus and species of related genera. In addition to the full-length $16 \mathrm{~S}$ rRNA gene, we also analysed portions of the following conserved genes: cpn60 (552 bp), recA (531 bp), pheS (455 bp) and rpoA (533 bp). The usefulness of these five regions in assessing phylogenetic relationships has been shown previously (Dobson et al., 2002; Eisen, 1995; Felis et al., 2001; Jian et al., 2001; Kwok \& Chow, 2003; Lloyd \& Sharp, 1993; Naser et al., 2005, 2007; Vandamme et al., 1996). We believe that the congruent data obtained through our MLSA approach creates a solid representation of the phylogenetic relationships among the bacterial species analysed, thus clarifying the taxonomic position of $P$. dextrinicus.

Phylogenetic trees were constructed using sequences from, in most cases, the type strains of two representatives from
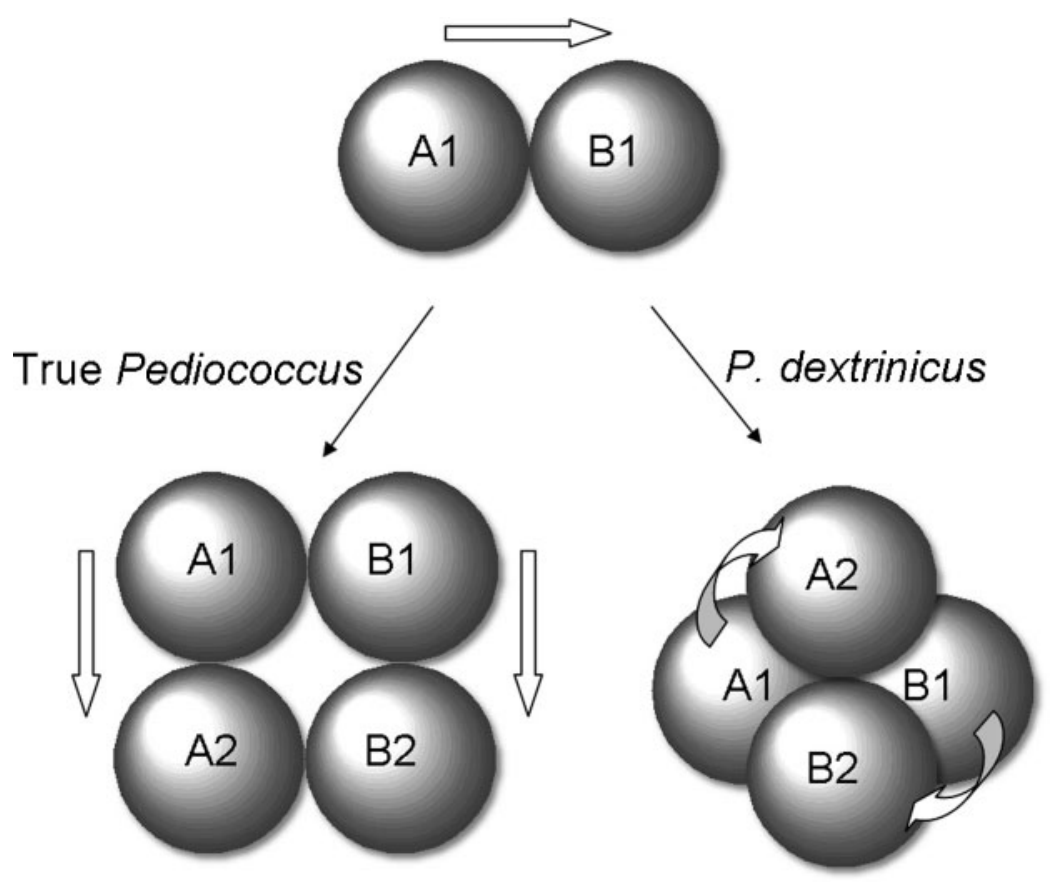

Fig. 2. Schematic representation of cell division from one to four cells for $P$. dextrinicus ATCC $33087^{\top}$ compared with true pediococci as followed by phase-contrast microscopy. The division of true pediococci is in two perpendicular directions in a single plane at right angles, while the division of $P$. dextrinicus cells is not in two perpendicular directions at right angles, nor is it in a single plane. 


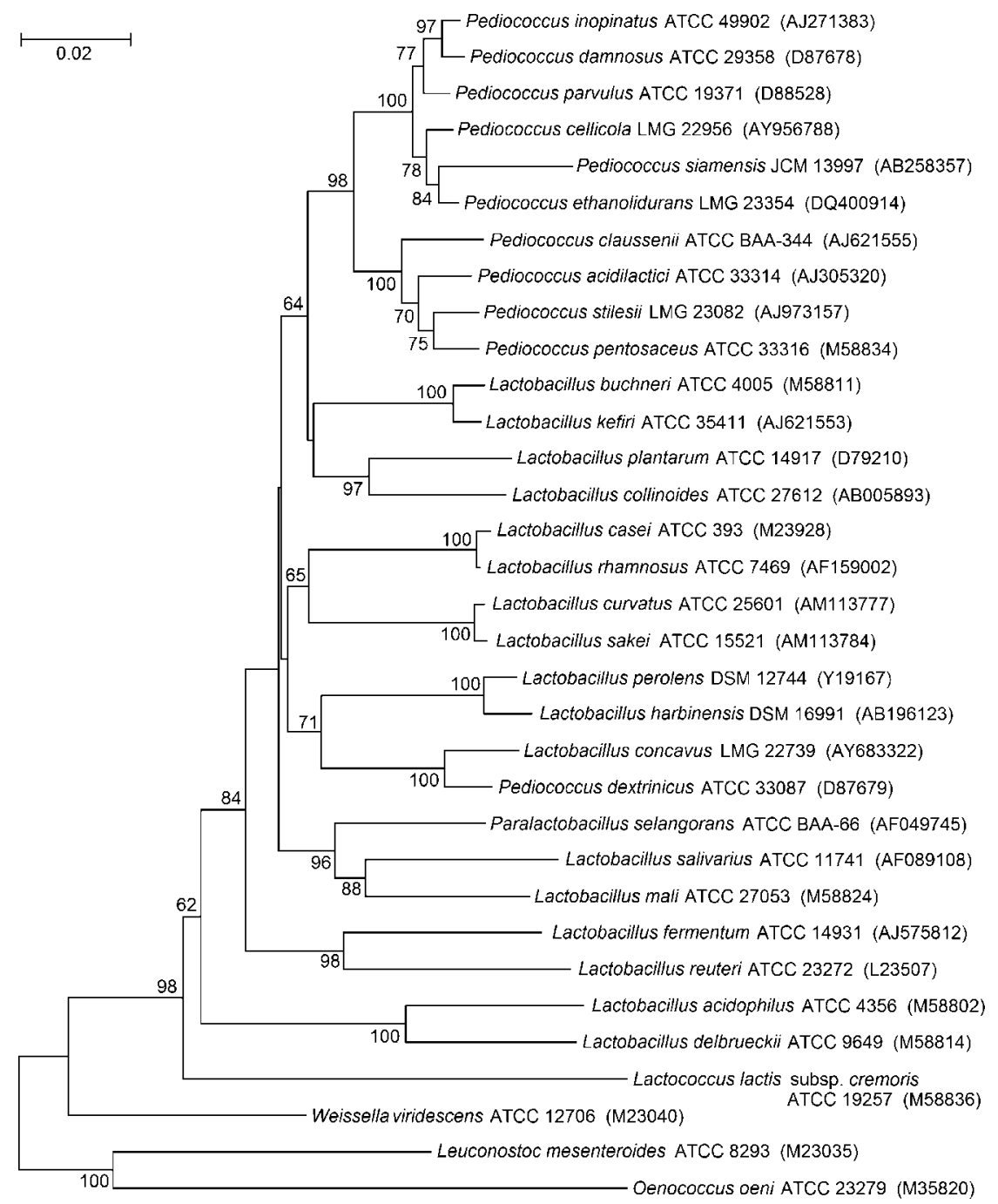

Fig. 3. Phylogenetic tree based on $16 \mathrm{~S}$ rRNA gene sequences illustrating the evolutionary relationship of Pediococcus dextrinicus with all other species of the genus Pediococcus and species that are representative of the major clades of the genus Lactobacillus. GenBank accession numbers are given in parentheses. Except for Lactobacillus fermentum, $P$. acidilacti and $P$. ethanolidurans, all strains are type strains. Bootstrap values $>60 \%$ are given at nodes as a percentage of 1000 replicates. Bar, $2 \%$ divergence.

each of the seven groups of the genus Lactobacillus as described in The Prokaryotes (Hammes \& Hertel, 2006). By using two representatives from each of these groups, the overall structure of the 16S rRNA gene tree remains the same as that shown in other publications regarding the current taxonomy of the genus Lactobacillus (Collins et al., 1991; Hammes \& Hertel, 2006; Holzapfel et al., 2001; Klein et al., 1998; Naser et al., 2007; Stiles \& Holzapfel, 1997). The best GenBank matches to $P$. dextrinicus (i.e. Lactobacillus concavus, Lactobacillus harbinensis and Lactobacillus perolens) were also included in the MLSA where sequences were available. The type strain sequences of the closely related genera Lactococcus, Leuconostoc, Oenococcus, Paralactobacillus and Weissella are included as outliers, again, where sequences were available.

Sequences were aligned with CLUSTAL_x (Thompson et al., 1997) and 16S rRNA gene alignments were visualized and

Fig. 4. Phylogenetic trees illustrating the evolutionary relationship of Pediococcus dextrinicus with all other species of the genus Pediococcus and species that are representative of the major clades of the genus Lactobacillus. GenBank accession numbers are given in parentheses. The strains used are the same as those in Fig. 3. Bootstrap values $>60 \%$ are given at nodes as a percentage of 1000 replicates. (a) PheS protein; (b) Cpn60 protein; (c) RecA protein; (d) RpoA protein. Bars, $2 \%$ divergence (a); $5 \%$ divergence (b, c, d). 


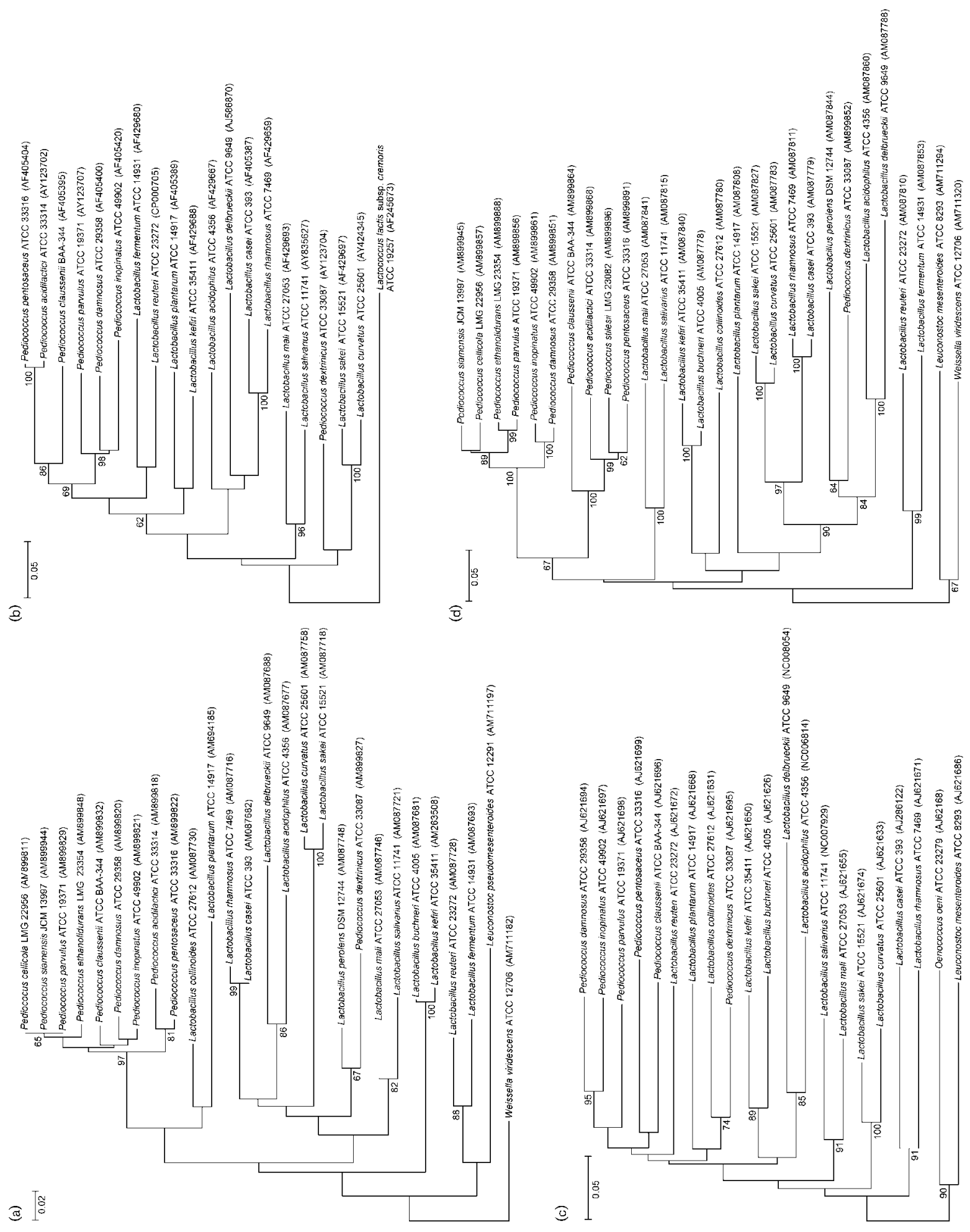


manually edited using the GeneDoc software program (Nicholas et al., 1997) to conform with structural information and inferred locations of conserved and variable regions (Neefs et al., 1993). Tree topology was evaluated using minimum evolution, maximum-parsimony, neighbour-joining and unweighted pair group method of arithmetic means (UPGMA) algorithms, with all methods producing similar overall topologies (data not shown). Fig. 3 and Fig. $4 \mathrm{a}-\mathrm{d}$ were inferred using the neighbour-joining maximum composite likelihood method (Saitou \& Nei, 1987) for the 16S rRNA gene and the PheS, Cpn60, RecA and RpoA proteins and are representative of the topology constructed by all four algorithms. Phylogenetic trees produced from DNA and translated protein sequences also produced similar overall topologies (data not shown). All phylogenetic trees were visualized and produced using MEGA version 4.0 (Tamura et al., 2007). The percentage of replicate trees in which the associated taxa clustered together at levels $>60 \%$ in the bootstrap test (1000 replicates) are shown next to the branches (Felsenstein, 1985).

$P$. dextrinicus consistently branches distant to other species of the genus Pediococcus for all five genetic loci (Fig. 3, Fig. $4 \mathrm{a}-\mathrm{d})$, grouping instead with members of the genus Lactobacillus. Based upon the 16S rRNA gene sequence analysis, the species most similar to P. dextrinicus are Lactobacillus concavus, Lactobacillus harbinensis and Lactobacillus perolens. This similarity is reinforced by the fact that the 16S rRNA gene of these Lactobacillus species shares 93$97 \%$ similarity with that of $P$. dextrinicus, while other members of the genus Pediococcus share only 90-92\% sequence similarity with $P$. dextrinicus. In contrast, the other ten species of the genus Pediococcus exhibit 93-97\% inter-species similarity for the $16 \mathrm{~S}$ rRNA gene.

Using 16S rRNA gene sequences, Collins et al. (1991) and Franz et al. (2006) both found, as did we (Fig. 3), that $P$. dextrinicus forms a distinct line of descent compared to the rest of the species in the genus Pediococcus. Here we have supported this finding with the application of a MLSA using PheS, Cpn60, RecA and RpoA sequences (Fig. 4a-d). This MLSA phylogenetic information, in conjunction with evidence that $P$. dextrinicus does not divide in two perpendicular directions in a single plane (Table 2; Figs 1 and 2) as do true pediococci (Table 2; Fig. 2), reinforces the phenotypic evidence (Table 1) indicating that this species does not belong within the genus Pediococcus, but rather does belong within the closely related genus Lactobacillus. We therefore propose that Pediococcus dextrinicus be reclassified as Lactobacillus dextrinicus comb. nov.

\section{Emended description of the genus Lactobacillus Beijerinck 1901}

This description of the genus Lactobacillus is based on that of Beijerinck (1901) as given by Kandler \& Weiss (1986), with the addition that cells may be rods, cocci or coccobacilli in shape.
Description of Lactobacillus dextrinicus comb. nov.

Lactobacillus dextrinicus (dex.tri'ni.cus. N.L. n. dextrinum dextrin; L. suff. -icus suffix used with the sense of belonging to; N.L. masc. adj. dextrinicus related to dextrin).

Basonym: Pediococcus dextrinicus (Coster and White 1964) Back 1978 (Approved Lists 1980).

Gram-positive, non-motile, non-spore-forming, facultative anaerobes. Cells are spherical, never elongated and may occur singly, in pairs or clusters and rarely in chains. Clusters of four may be observed, but not as the result of division in two perpendicular directions at right angles. Division does not occur in a single plane. Catalasenegative. Only (+)-L-lactic acid is produced [from maltose, dextrin and starch, but not from ribose, arabinose, xylose, mannitol, trehalose (10-90\% of strains), melezitose]; no ammonia is produced from arginine. Cells grow at pH 7.0, but not pH 4.5 (Dellaglio \& Torriani, 2006; Franz et al., 2006; Garvie, 1986; Stiles \& Holzapfel, 1997). The optimal temperature for growth is $32{ }^{\circ} \mathrm{C}$ (Cai et al., 1999), weak growth is observed at $43-45^{\circ} \mathrm{C}$, but not above $45{ }^{\circ} \mathrm{C}$ (Franz et al., 2006). G+C content of the DNA is 40$41 \mathrm{~mol} \%$ (Cai et al., 1999).

The type strain is ATCC $33087^{\mathrm{T}}\left(=\mathrm{DSM} 20335^{\mathrm{T}}=\mathrm{JCM}\right.$ $5887^{\mathrm{T}}=$ LMG $11485^{\mathrm{T}}=$ NCDO $\left.1561^{\mathrm{T}}\right)$.

\section{Acknowledgements}

Thanks to Drs Camilla Nesbø and Andrew Roger for helpful conversations concerning conservation profiles and phylogenetics, and to Dr Darren R. Korber for assistance with phase-contrast microscopy. C.M.D. and M.H. were awarded an Arthur Smyth Scholarship and a Graduate Scholarship, respectively, from the College of Medicine, University of Saskatchewan. M. H. also received Coors Brewing Company and Cargill Malt Scholarships from the American Society of Brewing Chemists Foundation. This research was supported by Molson Coors Brewing Company, Golden, Colorado, and the Natural Science and Engineering Research Council of Canada.

\section{References}

Back, W. (1978). Elevation of Pediococcus cerevisiae subsp. dextrinicus Coster and White to species status [Pediococcus dextrinicus (Coster and White) comb. nov.]. Int J Syst Bacteriol 28, 523-527.

Beijerinck, M. W. (1901). Sur les ferments lactiques de l'industrie. Arch Néer Sci Exactes Natur (Section 2) 6, 212-243.

Cai, Y., Kumai, S., Ogawa, M., Benno, Y. \& Nakase, T. (1999). Characterization and identification of Pediococcus species isolated from forage crops and their application for silage preparation. Appl Environ Microbiol 65, 2901-2906.

Collins, M. D., Rodrigues, U., Ash, C., Aguirre, M., Farrow, J. A. E., Martinez-Murcia, A., Phillips, B. A., Williams, A. M. \& Wallbanks, S. (1991). Phylogenetic analysis of the genus Lactobacillus and related lactic acid bacteria as determined by reverse transcriptase sequencing of 16S rRNA. FEMS Microbiol Lett 77, 5-12.

Coster, E. \& White, H. R. (1964). Further studies of the genus Pediococcus. J Gen Microbiol 37, 15-31. 
Dellaglio, F. \& Torriani, S. (2006). DNA-DNA homology, physiological characteristics and distribution of lactic-acid bacteria isolated from maize silage. J Appl Bacteriol 60, 83-92.

Dobson, C. M., Deneer, H., Lee, S., Hemmingsen, S., Glaze, S. \& Ziola, B. (2002). Phylogenetic analysis of the genus Pediococcus, including Pediococcus claussenii sp. nov., a novel lactic acid bacterium isolated from beer. Int J Syst Evol Microbiol 52, 2003-2010.

Eisen, J. A. (1995). The RecA protein as a model molecule for molecular systematic studies of bacteria: comparison of trees of RecAs and 16S rRNAs from the same species. J Mol Evol 41, 1105-1123.

Felis, G. E., Dellaglio, F., Mizzi, L. \& Torriani, S. (2001). Comparative sequence analysis of a $r e c A$ gene fragment brings new evidence for a change in the taxonomy of the Lactobacillus casei group. Int J Syst Evol Microbiol 51, 2113-2117.

Felsenstein, J. (1985). Confidence limits on phylogenies: an approach using the bootstrap. Evolution 39, 783-791.

Fox, G. E., Wisotzkey, J. D. \& Jurtshuk, P., Jr (1992). How close is close: $16 \mathrm{~S}$ rRNA sequence identity may not be sufficient to guarantee species identity. Int J Syst Bacteriol 42, 166-170.

Franz, C. M. A. P., Vancanneyt, M., Vandemeulebroecke, K., DeWachter, M., Cleenwerck, I., Hoste, B., Schillinger, U., Holzapfel, W. H. \& Swings, J. (2006). Pediococcus stilesii sp. nov., isolated from maize grains. Int J Syst Evol Microbiol 56, 329-333.

Garvie, E. I. (1986). Genus Pediococcus. In Bergey's Manual of Systematic Bacteriology, pp. 1075-1079. Edited by P. H. A. Sneath, M. E. Mair, M. E. Sharpe \& J. G. Holt. Baltimore, MD: Williams and Wilkins.

Gunther, H. L. \& White, H. R. (1961a). The cultural and physiological characters of the pediococci. J Gen Microbiol 26, 185-197.

Gunther, H. L. \& White, H. R. (1961b). Serological characters of the pediococci. J Gen Microbiol 26, 199-205.

Hammes, W. P. \& Hertel, C. (2006). The genera Lactobacillus and Carnobacterium. In The Prokaryotes: a Handbook on the Biology of Bacteria, pp. 320-403. Edited by M. Dworkin, S. Falkow, E. Rosenberg, K.-H. Schleifer \& E. Stackebrandt. New York, NY: Springer.

Holzapfel, W. H., Haberer, P., Geisen, R., Bjorkroth, J. \& Schillinger, U. (2001). Taxonomy and important features of probiotic microorganisms in food and nutrition. Am J Clin Nutr 73, 365S-373S.

Holzapfel, W. H., Franz, C. M. A. P., Ludwig, W., Back, W. \& Dicks, L. M. T. (2006). The genera Pediococcus and Tetragenococcus. In The Prokaryotes: a Handbook on the Biology of Bacteria, pp. 229-266. Edited by M. Dworkin, S. Falkow, E. Rosenberg, K.-H. Schleifer \& E. Stackebrandt. New York, NY: Springer.

Jian, W., Zhu, L. \& Dong, X. (2001). New approach to phylogenetic analysis of the genus Bifidobacterium based on partial hsp60 gene sequences. Int J Syst Evol Microbiol 51, 1633-1638.

Kandler, O. \& Weiss, N. (1986). Regular nonsporing Gram-positive rods. In Bergey's Manual of Systematic Bacteriology, vol 2, pp. 12081234. Edited by P. H. Sneath, N. Mair, M. E. Sharpe \& J. G. Holt. Baltimore, MD: William and Wilkins.

Klein, G., Pack, A., Bonaparte, C. \& Reuter, G. (1998). Taxonomy and physiology of probiotic lactic acid bacteria. Int J Food Microbiol 41, 103-125.

Kwok, A. Y. C. \& Chow, A. W. (2003). Phylogenetic study of Staphylococcus and Micrococcus species based on partial hsp60 gene sequences. Int J Syst Evol Microbiol 53, 87-92.
Liu, L., Zhang, B., Tong, H. \& Dong, X. (2006). Pediococcus ethanolidurans sp. nov., isolated from the walls of a distilled-spirit-fermenting cellar. Int J Syst Evol Microbiol 56, 2405-2408.

Lloyd, A. T. \& Sharp, P. M. (1993). Evolution of the recA gene and the molecular phylogeny of bacteria. J Mol Evol 37, 399-407.

Naser, S. M., Thompson, F. L., Hoste, B., Gevers, D., Dawyndt, P., Vancanneyt, M. \& Swings, J. (2005). Application of multilocus sequence analysis (MLSA) for rapid identification of Enterococcus species based on rpoA and pheS genes. Microbiology 151, 2141-2150.

Naser, S. M., Dawyndt, P., Hoste, B., Gevers, D., Vandemeulebroecke, K., Cleenwerck, I., Vancanneyt, M. \& Swings, J. (2007). Identification of lactobacilli by pheS and rpoA gene sequence analyses. Int J Syst Evol Microbiol 57, 2777-2789.

Neefs, J. M., Van de Peer, Y., De Rijk, P., Chapelle, S. \& De Wachter, R. (1993). Compilation of small ribosomal subunit RNA structures. Nucleic Acids Res 21, 3025-3049.

Nicholas, K. B., Nicholas, H. B., Jr \& Deerfield, D. W., II (1997). GeneDoc: analysis and visualization of genetic variation. EMBnet News 4 (2), 1-4. http://www.embnet.org/download/embnetnews/embnet_ news_4_2.pdf

Pederson, C. S. (1949). The genus Pediococcus. Bacteriol Rev 13, 225232.

Saitou, N. \& Nei, M. (1987). The neighbor-joining method: A new method for reconstructing phylogenetic trees. Mol Biol Evol 4, 406-425.

Simpson, W. J. (1994). Comments on the mode of division of Pediococcus spp. Lett Appl Microbiol 18, 69-70.

Simpson, W. J. \& Taguchi, H. (1995). The genus Pediococcus, with notes on the genera Tetragenococcus and Aerococcus. In The Genera of Lactic Acid Bacteria, pp. 125-172. Edited by B. J. Wood \& W. H. Holzapfel. London: Blackie Academic \& Professional.

Stiles, M. E. \& Holzapfel, W. H. (1997). Lactic acid bacteria of foods and their current taxonomy. Int J Food Microbiol 36, 1-29.

Tamura, K., Dudley, J., Nei, M. \& Kumar, S. (2007). MEGA4: molecular evolutionary genetics analysis (MEGA) software version 4.0. Mol Biol Evol 24, 1596-1599.

Tanasupawat, S., Pakdeeto, A., Thawai, D., Yukphan, P. \& Okada, S. (2007). Identification of lactic acid bacteria from fermented tea leaves (miang) in Thailand and proposals of Lactobacillus thailandensis sp. nov., Lactobacillus camelliae sp. nov., and Pediococcus siamensis sp. nov. J Gen Appl Microbiol 53, 7-15.

Thompson, J. D., Gibson, T. J., Plewniak, F., Jeanmougin, F. \& Higgins, D. G. (1997). The CLUSTAL_X windows interface: flexible strategies for multiple sequence alignment aided by quality analysis tools. Nucleic Acids Res 25, 4876-4882.

Vandamme, P., Pot, B., Gillis, M., deVos, P., Kersters, K. \& Swings, J. (1996). Polyphasic taxonomy, a consensus approach to bacterial systematics. Microbiol Rev 60, 407-438.

Weiss, N. (1992). The genera Pediococcus and Aerococcus. In The Prokaryotes, pp. 1502-1507. Edited by A. Balows, H. H. Trüper, M. Dworkin, W. Harder \& K.-H. Schleifer. New York, NY: Springer.

Woese, C. R. (1987). Bacterial evolution. Microbiol Rev 51, 221-271.

Zhang, B., Tong, H. \& Dong, X. (2005). Pediococcus cellicola sp. nov., a novel lactic acid coccus isolated from a distilled-spirit-fermenting cellar. Int J Syst Evol Microbiol 55, 2167-2170. 